\title{
Sterile Alpha and TIR Motif-Containing Protein 1
}

National Cancer Institute

\section{Source}

National Cancer Institute. Sterile Alpha and TIR Motif-Containing Protein 1. NCI

Thesaurus. Code C102781.

Sterile alpha and TIR motif-containing protein 1 (724 aa, $79 \mathrm{kDa}$ ) is encoded by the human SARM1 gene. This protein is involved in immune responsive signaling. 